\title{
The Comparative Study of Papain Enzyme from Papaya Fruits California variant and Indonesian Local variant
}

\author{
Diah Ratnaningrum ${ }^{1}$, Wawan Kosasih, ${ }^{1}$ Sri Priatni ${ }^{1}$ \\ ${ }^{1}$ Research Unit for Clean Technology, Indonesian Institute of Sciences (LPTB-LIPI), Jalan Sangkuriang, \\ Bandung 40135 \\ *Corresponding author: diahratnaningrum09@gmail.com
}

\begin{tabular}{l} 
A $R$ T I C L E I N F O \\
\hline Article history: \\
Received date :2 May 2017 \\
Revised date : 29 May 2017 \\
Accepted date: 13 June 2017 \\
Available online at : \\
http://inajac.lipi.go.id \\
\hline $\begin{array}{l}\text { Keywords: } \\
\text { Protease enzyme, isolation, papaya }\end{array}$ \\
latex, california var., local var.
\end{tabular}

\section{INTRODUCTION}

Papaya (Carica papaya) is a common fruit grown in tropical region in the world [1]. Papaya tree is a native plant from Central of America and it is known well for health of human body. Papaya is rich of antioxidant (vitamin $\mathrm{C}$, vitamin $\mathrm{A}$ and vitamin $\mathrm{E}$ ); the minerals, folate acid and fiber [2]. Papaya plant has the important role in producing papain enzyme. It is the most important species and generally grown from seeds for consumption as a commercial fresh fruit [3]. Papaya contains rich papain enzyme, present in the fruit, latex, stem and leaves [4,5]. Papain is a natural proteolityc enzyme from the cysteine proteinase family [6]. Protease is the single class of enzymes which the utilization of papain is generally used in manufacture of sugar syrup liquid from starch, clotting dairy (cheese), meat tenderizer, leather, paper and pulps, cosmetic, stabilizer (beer), pharmaceutical industry, cosmetics, detergents, textile, and production of peptides
$[7,8,9]$. It is also used in antihelmintics, relives dyspepsia, cures diarrhea, pains of burns and topical use, bleending haemorrhoids, stomachic, and whooping cough [2].

Papain is an endolytic plant cysteine protease which is isolated from papaya latex [10]. The latex is source of cysteine endopeptidase including papain, chymopapain, glycyl endopeptidase and caricain, which constitute more than $80 \%$ of the whole enzyme fraction [11]. Papain (E.C.3.4.22.2) is a simple and a cysteine protease enzyme which contains 212 asam amino acid residue chains with a molecular mass of $21.000-23.000 \mathrm{~g} / \mathrm{mol}$ or 23.406 Dalton $[12,13,14]$ and its optimum $\mathrm{pH}$ maximum activity is around 6.0 to 7 [15]. Papain consists of a single polypeptide chain with tree disulfide bridges and sulfuhydryl group for activity of the enzyme [15].

Carica papaya contains many biologically active compounds, among others chymopapain and papain, it supposed to help digestion system [16] and it can be investigated for 
antibacterial activity againts some human pathogenic bacteria [15]. It is reported that papaya latex has ability as antibacteria material and anti inflamantion [16]. Some existing research among others, are papain, a plant enzyme of biological importance: a review [17], traditional medicinal uses of carica papaya [2], comparative analysis of papain different varieties of papaya plant latex [6], chemical composition of carica papaya flower (paw-paw) [17], evaluation of dryer techniques measuring proteolytic activity of papain obtained from unripe fruit skin juice [18]. A similar extraction method has been carried out using carica papaya, however the research was focus on the purification enzyme using california var local and local var.

The objective of this study is to compare the California var. and Indonesian local var. of papaya fruits in papain enzyme production and also to characterize the enzyme properties.

\section{EXPERIMENTAL SECTION}

\subsection{Materials and Instrument}

Papaya latex was harvested directly from California var. and local var. of papaya fruits at a papaya farm in Bandung, Indonesia.

\subsection{Methods}

\subsubsection{Extraction of Papain Enzyme}

The papain enzyme from papaya latex was extracted by modification of Hitesh Pates et. al., and Margarita M.A.-Mahecha methods $[13,14]$. Latex of papaya was obtained from papaya raw fruits, the process itself is preceded by making incisions vertical direction from top to bottom with $2-3 \mathrm{~mm}$ of depth and $2 \mathrm{~cm}$ distance between each incision. Tapping process is limited only 5 fruits a day and placing container before all process is begin to collect latex. The latex was collected in a beaker glass and water diluted at ratio of $1: 10(\mathrm{w} / \mathrm{v})$, added $0,5 \%$ of sodium metabisulfite $(\mathrm{w} / \mathrm{w})$ and storage at $-5{ }^{\circ} \mathrm{C}$ till further used. The prepared papain enzyme was then heated and stirred until $75{ }^{\circ} \mathrm{C}$ and cooled to $30{ }^{\circ} \mathrm{C}, \mathrm{pH}$ of enzyme was adjusted to $\mathrm{pH}$ of
6.3. Furthermore, the enzyme was added with $1 \%$ of Na- EDTA and homogenized for 15 minutes. Enzyme solution was precipitated with $10 \%$ of ethanol and filtrated by using a vacuum filter. The precipitation of enzyme was continued by adding with ethanol (ratio 1:2 and 1:3) and placing at $4{ }^{\circ} \mathrm{C}$ for overnight. The precipitated enzyme was then centrifuged at $7000 \mathrm{rpm}$ for 10 minutes. Papain extract was determined the enzyme activity and soluble protein content.

\subsubsection{Purification of Papain Enzyme}

The purification of papain enzyme was carried out by Bollag et al [18] method. 1 gram of papain extract was dialyzed by a dialysis tubing for 4 hours. DEAE sepharose column was prepared by adding the DEAE sepharose in $1 \mu \mathrm{M}$ of buffer Tris to a $5 \mathrm{~mL}$ column. Fractionation of papain was carried out by elution with $0.0 \mathrm{M}, 0.05 \mathrm{M}, 0.1 \mathrm{M}, 0.2$ $\mathrm{M}$ and $0.5 \mathrm{M}$ of $\mathrm{NaCl}$ in buffer tris $\mathrm{pH}$ 8.5. Each fraction was pooled in a tube and the absorbance was measured at $280 \mathrm{~nm}$.

\subsubsection{Molecular Weight Analysis}

Sodium dodecyl sulphate - polyacrylamide gel electrophoresis (SDS-PAGE) was done on all samples and protein marker on a discontinuous buffer system according to Laemmli in Bollag et al. method [18]. $20 \mu \mathrm{L}$ of each sample was added with $40 \mu \mathrm{L}$ of sample buffer. Samples were placed in a foam rack and placed in a beaker of boiling water for $4 \mathrm{~min}$. The prepared polyacrylamide gel was placed in an electrophoresis unit. Running buffer was filled at the upper buffer chamber of the gel until the buffer reaches halfway between the tops of the short and long glass plates. $5 \mu \mathrm{L}$ of standard protein markers and $25 \mu \mathrm{L}$ of each of samples were added to the polyacrylamide gel. Electrophoresis was conducted at a constant $200 \mathrm{~V}$ for 30 minutes. The gel was removed and placed in staining solution.

\subsubsection{Determination of Papain Activity}

Papain activity was determined by using the modification of Afaq, S. and Iqbal, J. methods [19]. $1 \mathrm{~mL}$ of casein $2 \%$ was mixed with $2 \mathrm{~mL}$ of phosphate buffer $0,1 \mathrm{M} \mathrm{pH} \quad 7,0$ and 
incubated at $50{ }^{\circ} \mathrm{C}$ for 5 minutes. This solution was added with $0.5 \mathrm{~mL}$ of papain sample and incubated at $50{ }^{\circ} \mathrm{C}$ for 20 minutes. The reaction was stopped with addition of $1 \mathrm{~mL}$ of TCA $20 \%$ and incubated at $50{ }^{\circ} \mathrm{C}$ for 20 minutes. Control sample solution was prepared by the addition of $50 \mu \mathrm{L}$ L-cystein chloride with $2 \mathrm{~mL}$ of phosphate buffer $0,1 \mathrm{M}$ pH 7,0, $0.5 \mathrm{~mL}$ of papain sample and $1 \mathrm{~mL}$ of TCA 20 $\%$ and incubated at $50{ }^{\circ} \mathrm{C}$ for 20 minutes. This solution was added with $1 \mathrm{~mL}$ of casein $2 \%$ and incubated at $50{ }^{\circ} \mathrm{C}$ for 20 minutes. Tyrosine $(0-450 \mu \mathrm{g} / \mathrm{mL})$ was used as the standard solution. The sample and control sample were centrifuged at $4{ }^{\circ} \mathrm{C}, 6.000 \mathrm{rpm}$ for 10 minutes and the absorbance of supernatant was measured by a spectrophotometer UV-Vis at $280 \mathrm{~nm}$. The unit activity of papain enzyme was calculated based on $\mu \mathrm{g}$ tyrosine per $\mathrm{g}$ of enzyme.

\subsubsection{Determination of Soluble Protein Content}

Soluble protein content was analyzed by using the modification of Lowry method. ${ }^{[20]}$ $0.5 \mathrm{ml}$ of latex extract was added to a reaction tube and mixed with $5 \mathrm{ml}$ of solution $\mathrm{C}(50 \mathrm{ml}$ of Lowry A and $1 \mathrm{ml}$ of Lowry B solution), then incubated at room temperature for 30 minutes. The sample solution was mixed with $0.5 \mathrm{ml}$ of Folin reagent $1 \mathrm{~N}$ and the absorbance was measured by a spectrophotometer UV-Vis at $500 \mathrm{~nm}$. A series concentration of bovine serum albumin (BSA) was used for standard curve of protein.

\section{RESULTS AND DISCUSSION}

The total weight of latex from each papaya sample is 30 gram, it was obtained from each five papaya fruits. To compare the yield of papain from California var. and Local var. latex, papain from papaya latex was precipitated by ethanol with ratio $1: 2$ and $1: 3$. The yield of crude papain was determined and the results was shown on Table 1 .
Table 1. The yield of crude papain from California var. and Local var. of papaya Latex

\begin{tabular}{lccccc}
\hline & \multirow{2}{*}{$\begin{array}{c}\text { Weight } \\
\text { of Latex } \\
\end{array}$} & \multicolumn{2}{c}{$\begin{array}{c}\text { Crude } \\
\text { papain } \\
\text { (g) }\end{array}$} & \multicolumn{2}{c}{$\begin{array}{c}\text { Yield } \\
(\mathbf{\%})\end{array}$} \\
\cline { 3 - 6 } & $\mathbf{1 : 2}$ & $\mathbf{1 : 3}$ & $\mathbf{1 : 2}$ & $\mathbf{1 : 3}$ \\
\hline Local var. & 15 & 3.73 & 2.92 & 24.87 & 19.47 \\
\hline $\begin{array}{l}\text { California } \\
\text { var. }\end{array}$ & 15 & 1.6 & 2.2 & 10.67 & 14.67 \\
\hline
\end{tabular}

As shown on Table 1, the highest yield of crude papain was obtained from local var. papaya latex $(24.87 \%)$ which precipitated by ethanol with ratio 1:2. The yield of crude papain was influenced by the solubility of protein in ethanol. During the ethanol addition, there is an interaction between ethanol and water that causes the occurrence of white precipitation and the solubility of papain decreased [21]. Basic principle of precipitation with ethanol is lowering the dilution level of protein to solvent. Mahecha, et.al. [14] reported that latex: alcohol ratio and drying method was important factor in papain extraction from latex of Carica papaya L. cv. Maradol.

Before purification, papain from papaya latex was extracted by several treatments to separate the impurities that contained in papaya latex. Papain extract was analyzed for the activity of papain enzyme, soluble protein content and specific enzyme activity. The activity of papain enzyme was determined based on Afaq, S. and Iqbal, J. methods which calculated based on $\mu \mathrm{g}$ tyrosine per $\mathrm{g}$ of enzyme [19]. One unit protease activity (U) defined as the amount of enzyme needed to produce one $\mu \mathrm{g}$ tirosin/minute of enzyme solvent from casein substrate on the test condition. Meanwhile, specific enzyme activity was defined as a unit protelitic activity per miligram protein. Value specific enzyme activity was obtained by deviding enzyme activity unit with amount protein contained in the extract. The results are presented on Table 2. 
Table 2. Analysis data of enzyme activity of California and Local Papaya Latex

\begin{tabular}{ccccc}
\hline Samples & $\begin{array}{c}\text { Ratio } \\
\text { Filtrat:Etanol }\end{array}$ & $\begin{array}{c}\text { Enzyme } \\
\text { Activity } \\
(\mathbf{U} / \mathbf{m L})\end{array}$ & $\begin{array}{c}\text { Soluble } \\
\text { Protein } \\
(\mathbf{m g} / \mathbf{m L})\end{array}$ & $\begin{array}{c}\text { Specific Enzyme Activity } \\
(\mathbf{U} / \mathbf{m g})\end{array}$ \\
\hline Local var. & - & $678 \pm 36.78$ & $1.685 \pm 0.06$ & 402.37 \\
& $1: 2$ & $3154 \pm 11.31$ & $0.940 \pm 0.08$ & 3355.32 \\
\hline $\begin{array}{c}\text { California } \\
\text { var. }\end{array}$ & $1: 3$ & $490 \pm 2.83$ & $1.912 \pm 0.2$ & 256.28 \\
& $1: 2$ & $396 \pm 42.43$ & $4.082 \pm 0.03$ & 97.01 \\
& $1: 3$ & $1203 \pm 84.85$ & $0.428 \pm 0.03$ & 2810.75 \\
\hline
\end{tabular}

Note: The Data was presented in means \pm SD

On Table 2 shows that there is increasing enzyme activity after precipitation ethanol compare to crude enzyme, as well as spesific enzyme activity. The highest of activity protease enzyme, soluble protein and activity specific content are obtained from the local papaya with the treatment comparison filtrate and ethanol of 1:2. The results are $3154 \pm$ $11.31 \mathrm{unit} / \mathrm{mL}$, solubility protein of $0.94 \pm$ $0.08 \mathrm{mg} / \mathrm{mL}$ and specific enzyme activity of $3355.32 \mathrm{unit} / \mathrm{mg}$ protein, respectively. It is assumed that enzyme isolated from different sources will resulted in different activity of enzyme as well. As comparition, other research by Jeana S. Macalood, et.al. [22] reported that protease activity at $\mathrm{pH} 5.5$ is 2655 units/g and $\mathrm{pH} 9.0$ protease activity is 28 units/g, (crude papain). Rifah Hestyani A., et al. [23] also reported the proteolytic activity of papain from varieties of Calina was of $687 \mathrm{u} / \mathrm{g}$.

Based on the data, the highest yield of crude papain and specific enzyme activity was obtained from local papaya with ratio 1:2. This sample was then followed by the purification step. Before to purification process, papain enzyme was dialyzed by using a cellophane tube. Dialysis process is a process to separate a bigger molecules on the solution or solvent using a semi-permiable membrane that only could be passed by smaller molucles [23]. The purification of papain enzyme was carried out by using a DEAE sepharose column and eluted gradiently with $\mathrm{NaCl}$ in buffer tris $\mathrm{pH}$ of 8.5 .
This purification is based on ion exchange principles which permits the protein to bind even when a large buffer volume is applied, making this method useful for an initial purification step from a crude extract. The chromatogram of papain purification is presented in Figure 1.

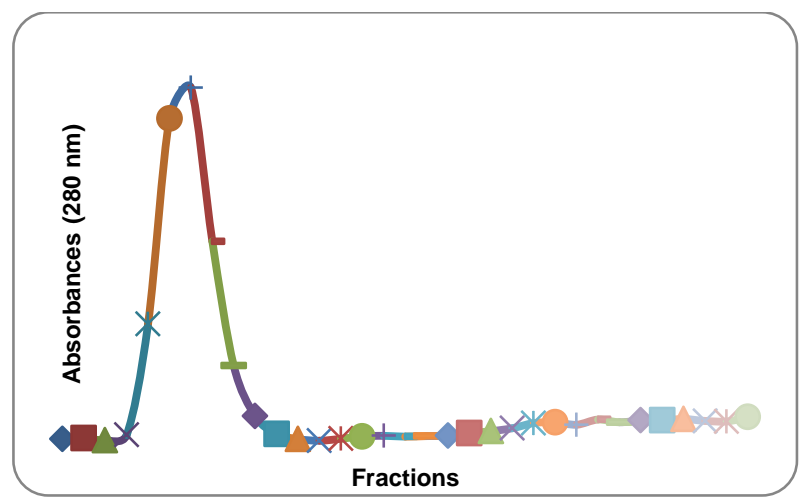

Figure1. Chromatogram of papain purification by using DEAE sepharose column.

Figure 1 showed that the peak in chromatogram is between fraction 5 to fraction 11 with the highest absorbance at fraction 7 (F7). The purification by ion exchange principles involve some stages, includes the initial stage for equilibration of ion exchanger, sample application and adsorption in which solute molecules carrying the appropriate charge displace counter-ions and bind reversibly to the gel. On final stage, substances are removed from the column by changing to elution conditions unfavourable for ionic 
bonding of the solute molecules and removal from the column of substances not eluted under the previous experimental conditions. The enzyme fraction F7 was then characterized its activity and molecular weight. The activity of enzyme fraction F7 was $202.33 \mathrm{U} / \mathrm{mL}$. The data shown that the enzyme activity was lower than that in the crude papain enzymes. We assumed that the complex formation with inhibitors influences to the activity of enzymes. Inhibitors can induce alterations in the results of the catalytic constant and number of sulfhydryl groups per mol papain [24].

Figure 2 shows that SDS PAGE profile of papain enzyme that is obtained from purification process (F7, F8, F9) has a major single band between $17-28 \mathrm{kDa}$. This indicated that the molecular weight of papain from local papaya is $17-28 \mathrm{kDa}$.

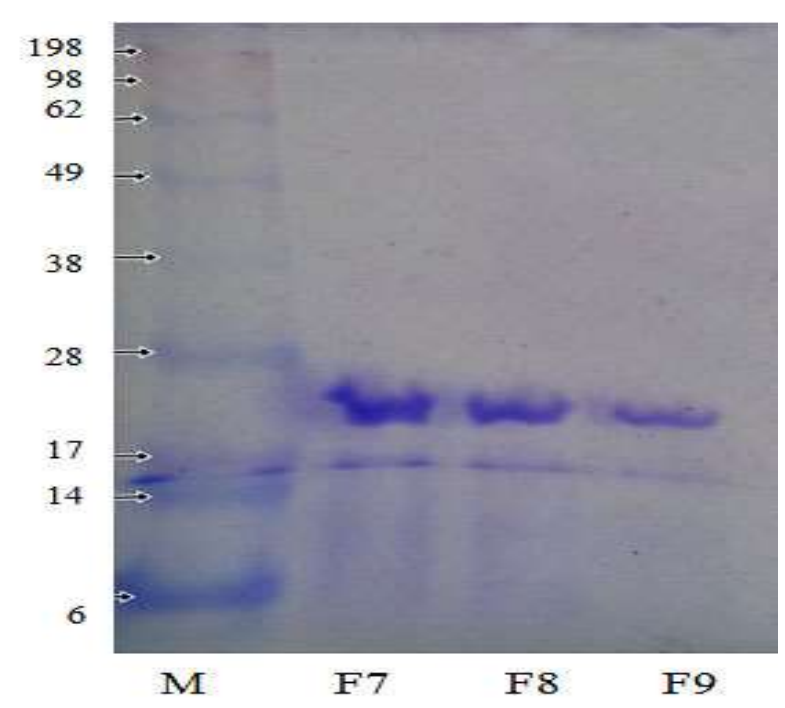

Figure 2. SDS PAGE profile of papain enzyme obtained from purification process by a DEAE Sepharose column. M: protein marker, F7, F8, F9: Fraction 7, 8, 9

Rubens Monti, et.al. [25] reported the pure papain exhibited aparent molecular masses of $21 \mathrm{kDa}$ and the classical papain $21.3 \mathrm{kDa}$, when G-75 Sephadex was used. By using the methodology in our study, DEAE sepharose can be used for papain purification from papaya latex. Ion exchanger are typically composed of a charge (ion exchange) group attached to an insoluble matrix. A positively charge group, such as DEAE (diethyl amino ethyl) defines the matrix as an anion exchange matrix [18].

\section{CONCLUSION}

The highest yield of crude papain was obtained from local var. of papaya latex $(24.87 \%)$. The highest of enzyme activity, soluble protein and specific enzyme activity are obtained from the local papaya at $3154 \pm$ $11.31 \mathrm{unit} / \mathrm{mL}$, solubility protein of $0.94 \pm 0.08$ $\mathrm{mg} / \mathrm{mL}$ and spesifik enzyme activity of $3355.32 \mathrm{unit} / \mathrm{mg}$ protein, respectively. The activity of enzyme fraction F7 obtained from purification by DEAE sepharose column is $202.33 \mathrm{U} / \mathrm{mL}$ dan the molecular weight of this fraction is between $17-28 \mathrm{kDa}$.

\section{ACKNOWLEDGMENT}

This work was supported under Indepently Project of Research Unit for Clean Technology year 2016.

\section{REFERENCES}

[1]. Islam N. and Eunice M. MolinarTorobio, 2013. Development of a meat tenderizer Based on Papaya Peel. Ridtec. Volume. 9. No.2.

[2]. Aravind G., Debjit Bhoomik., Duraivel. S and Harish G., 2013. Traditional and Medicinal Uses of Carica Papaya. Journal of Medicinal Plants Studies. Vol. 1 Issue: 1. ISSN: 2320-3862.

[3]. Iiondu E.M, Evaluation Some Aqueous Plant Extracts Used in The Control Paw paw Fruit (Carica papaya L) Rot Fungi., 2011. Journal of Applied Biosciences. Vol. 37. 2419-2424.

[4]. Papain, 2011. Fruit of Angels "Exotic for Health".

[5]. C.S.Chidan K., R. Mythily and S. Chandraju. 2012. A Rapid and Sensitive Extraction of Sugar from Papaya Peels. Sholars Research Libray. Der. Pharma Chemica. 4(4):1631-1634. ISSN 0975413X. Coden (USA): PCHHAX. 
[6]. Manjunath hullikere M., Chandrashekhar G.,Vijay R and Mahesh M., 2014. Comparative Analysis of papain from Different Varietes of Papaya Plant Latex. Internasional Journal of Agriculture and Food Science. ISSN 2249-8516.

[7]. Yuhai He., Syed Mohd bin Tuak Chat., FuiChin Choong., 2014. Furification of Papain from Unclarified Papaya Juice Using Reversed Phase Expanded Ben Adsorption Chromatography (RPEBAC). Journal of Indsutrial and Engineering Chemistry. Volume 20. Issue 6. p. 4239-4297.

[8]. Faizah H dan Farida Hanum Hamzah, 2010. Pemurnian Papain, Pengembangan Produk Losion Pemutih Kulit dan Sabun Pembersih Muka. J. Agropilus. Vol. 20. Nomor: 03. ISSN. 0854-0128.

[9]. E. Fitasari, 2012. Penggunaan Enzim Papain dalam Pakan Terhadap Karakteristik Usus dan Penampilan Produksi Ayam Pedaging. Buana Sains Vol. 12. No. 1: 7-16.

[10]. Amri, E. and Mamboya, F., 2012. Papain, Plant Enzyme of Bological Importance. American Journal of Biochemistry and Biotechnology, 8(2), $99-104$.

[11]. Chaman Mehta., M.P. Rajesh V.Sridevi., Divya M.L and Satya Ch.V. 2007. Optimization of Papain Extraction by Aquous Two-Phase System Using Response Surface Methodology. J. Innovative Research in Science, Engineering and Technology. (ISO 3297: Certified Organization). Vol. 2. Issue 8. 2013). ISSN: 2319-8753.

[12]. Thato T Tswiiio., Orose Rugchati., Duangporn Premjet and Niran Aeksiri, 2017. Application of an Aqueous TwoPhase Technique for Extraction of Papain from Carica Papaya Latex. Int'l Journal of Advances in Chemical Engg and Biological Sciences (IJACEBS) Vol. 4. Issue 1 ISSN 2349-1507 EISSN 23491515 .
[13]. Patel Hitesh., Bhai Manojbhai N., Barad Mayuri A., Dalvadi A., and Dalsania Kiranben V, 2012. Exraction and Application of Papain Enzyme On Degradation of Drug.UPBS. Volume 2.Issue 3, p.113-115.

[14]. Margarita M. Andrade-Mahecha., Olga Morales-Rodriguez and Hugo A. Martinez-Correa. 2011. Study of The Extraction Process of Papain from Latex of Papaya (Carica papaya L.) Fruits CV. Maradol. Acta Agronomica. 60 (3). p. 217-223.

[15]. Nur Dianaty Binti Nordin, 2010. The Extraction of Papain from Papay Leaves. Thesis. Faculty of Chemical and Natural Resources Engineering. University Malaysia Pahang.

[16]. Ashok CD., Parchu BM., Umesh JU and Manohar PV. 2011. Antibacterial and Antioxidant Activity pf Plant Latex. J. Pharm Res 4:406-407.

[17]. Stephen C.U., Emmanuel O., Chukwu Henry $\mathrm{C}$ and Ezikpe Chizaram. Composition of Carica Papaya Flower (paw-paw). Internasional Journal of Scientific Research and Engineering Studies. Volume 2. Issue 3. 2015. ISSN: 2349-8862.

[18]. Bollag et.al. 1996. Protein Methods. Wiley. Liss. Inc. USA.

[19]. Afaq S., Iqbal. 2001. Immobilization and Stabilizatio of Papaya on Chelating Sepharose: a Metal Chelate Regenerable Carrier. Electron J. Biotechnology 4:120-124.

[20]. Lowry O. H., Rosenbrough., N.J, Farr, A.L. Randall,. R.J. 1951. Protein Measurement. Biol Chem. 193. p 265275.

[21]. Firman Sebayang. 2006. Immobilisasi Enzim Papain dari Getah Buah Pepaya dengan Alginat. Jurnal Komunikasi Penelitian. Volume. 10(2).

[22]. Jeana S. Macalood., Helen J. Vicente., Renato D. Boniao., Jessie G. Gorospe 
and Elnor C. Rao.,2013. Chemical Analysis of Carica Papaya L. Crude Latex. American Journal of Palnt Sciences.. 4. 1941-1948.

[23]. Rifah Hestyani A., Budiatman S and Harsi D.Kusumaningrum., Aktivitas Antibakteri Getah Pepaya Kering terhadap Staphlococcus aureus pada Dangke. J. Teknol dan Industri pangan. Vol. 23 No. 1. ISSN: 1978-7788.

[24]. Smith.BJ.,1984. SDS Polyacrilamide Gel Electrophoresis of Protein.In Walker JM. Proteins Methoda in Moleculer Biology. Volume 1. Clifton: Humana Pr. halm. 41-45.

[25]. Rubens Monti., Carmelita A. Basilio., Henrique C. Trevisan and Jonas Contiero., 2000. Purification of Papain from Fresh Latex of Carica papaya. Brazilian Archives of Biology and Technology, v.43, n.5, p. 501-507, 